REPORTS OF MORPHOLOGY
Official Journal of the Scientific Society of Anatomists,
Histologists, Embryologists and Topographic Anatomists
of Ukraine
journal homepage: https://morphology-journal.com

\title{
Features of the frequency of angio-, retino- and neuropathy, general clinical and anthropometric parameters in patients with type 1 diabetes with different levels of albumin in the urine depending on the level of cystatin C
}

\author{
Kryvoviaz Yu.O. ${ }^{1}$, Vernigorodskiy V.S. ${ }^{1}$, Dzevulska I.V. ${ }^{2}$, Shevchuk Yu.G. ${ }^{1}$, Zhuchenko P.S. ${ }^{1}$ \\ ${ }^{1}$ National Pirogov Memorial Medical University, Vinnytsia, Ukraine \\ ${ }^{2}$ Bogomolets National Medical University, Kyiv, Ukraine
}

\section{ARTICLE INFO}

Received: 24 June, 2020

Accepted: 22 July, 2020

UDC: $616.379-$

008.64:577.112:616.61-07-084

\section{CORRESPONDING AUTHOR}

e-mail: juliak3x@gmail.com Kryvoviaz Yu.O.
Cystatin C improves the risk stratification among people with diabetic nephropathy, the risk of mortality, cardiovascular disease, disorders of the visual organ and nervous system in the preclinical and early stages. The aim of the study was to study the frequency of angio-, retino- and neuropathy, as well as differences in general clinical and anthropometric parameters in patients with type 1 diabetes (T1D) with different levels of albumin in the urine depending on cystatin $C$. The sample was 78 men and 62 women aged 22-26 years, patients with T1D, who were hospitalized in the therapeutic department №1 and №2 of the Vinnytsia Regional Highly Specialized Endocrinology Center. The control group consisted of 8 healthy men and 13 healthy women of the same age. The level of microalbuminuria and cystatin $C$ was determined for all patients by enzyme-linked immunosorbent assay. The frequency of angio-, retino- and neuropathy, general clinical (systolic, diastolic, pulse) and anthropometric (height, weight, body surface area, waist circumference, body mass index) was assessed indicators. Statistical processing of the obtained results was performed in the license package "Statistica 5.5", using non-parametric evaluation methods. It was found that in the group of men with cystatin $C<0.9$, and in women with cystatin $C>0.9$ with increasing albuminuria, the percentage of patients with more severe microvascular complications of T1D. In patients with diabetes mellitus 1 compared with the control group systolic blood pressure is significantly higher and increases with increasing albumin levels in the urine (with cystatin C<0.9 - in men with normo-, microalbuminuria and proteinuria by $7.14 \%, 8.1 \%$ and $10.8 \%$; in women with normo-, microalbuminuria by $7.5 \%$ and $10.0 \%$, with cystatin C>0.9 - in men with normo-, microalbuminuria by $4.9 \%$ and $7.2 \%$, in women with proteinuria by $19.5 \%$ ). Similar changes were found for diastolic blood pressure (with cystatin $C<0.9$ - in men with proteinuria by $13.0 \%$; in women with normo-, microalbuminuria by $11.4 \%$ and $13.4 \%$; with cystatin $C>0.9$ - in men with microalbuminuria by $9.0 \%$; in women with normo- and proteinuria by $9.5 \%$ and $21.5 \%$ ) and heart rate (with cystatin $\mathrm{C}<0.9$ - in men with microalbuminuria and proteinuria by $18.4 \%$ and $12.6 \%$, in women with microalbuminuria by $9.13 \%$; with cystatin $C>0.9$ - in men with microalbuminuria by $12.0 \%$, in women with normo-, microalbuminuria and proteinuria by $10.1 \%, 16.3 \%$ and $25.3 \%)$. In patients with T1D compared to the control group, the length of the body is significantly smaller and decreases with increasing levels of albumin in the urine (with cystatin $\mathrm{C}<0.9$ - in men with normo-, microalbuminuria and proteinuria by $3.6 \%, 6.7 \%$ and $9.0 \%$; women with microalbuminuria by $1.9 \%$, with cystatin C>0.9 - in men with normo-, microalbuminuria by $5.2 \%$ and $7.3 \%$, in women with normoalbuminuria and proteinuria by $2.6 \%$ and $4.3 \%$ ). Similar changes were found in men for body weight (with cystatin $\mathrm{C}<0.9$ - with microalbuminuria and proteinuria by $13.6 \%$ and $30.1 \%$; with cystatin C>0.9 - with normo- and microalbuminuria by $10.2 \%$ and $25.4 \%$ ) and body surface area (with cystatin C<0.9 - with normo-, microalbuminuria and proteinuria by $5.8 \%, 10.8 \%$ and $18.9 \%$; with cystatin C>0.9 - with normo- and 
microalbuminuria by $8.2 \%$ and $16.2 \%)$. The size of the waist circumference in patients with T1D with normoalbuminuria is significantly higher, and in patients of other groups significantly less than in healthy subjects (with cystatin $\mathrm{C}<0.9$ - with normo-, microalbuminuria and proteinuria by $3.8 \%, 1.2 \%$ and $5.2 \%$; cystatin $C>0.9$ - with microalbuminuria by $5.1 \%)$. Compared to healthy women, the waist circumference was significantly higher in sick women (with cystatin $C<0.9$ - with normo- and microalbuminuria by $11.2 \%$ and $10.7 \%$; with cystatin C>0.9 - with normo- and proteinuria by $9.7 \%$ and $6.0 \%)$. In patients with T1D men with proteinuria compared with the control group, the value of the body mass index was significantly lower by $9.7 \%$ (cystatin $C<0.9$ ). The value of the body mass index was significantly higher in patients with normoalbuminuria and microalbuminuria - by $11.8 \%$ and $17.7 \%$ (cystatin $C<0.9$ ), respectively, and in patients with proteinuria by $7.2 \%$ (cystatin C>0.9) compared with healthy women. Thus, between healthy and patients with T1D with varying degrees of albuminuria, differences in general clinical and anthropometric parameters were found, and they are greater the higher the level of cystatin $C$.

Keywords: type 1 diabetes, cystatin C level, urinary albumin level, angio-, retino- and neuropathy, general clinical indicators, anthropometric indicators.

\section{Introduction}

Today, type 1 diabetes (T1D) occupies one of the first places in terms of severity of its complications and mortality, and the scale of the prevalence of this pathology and its complications is becoming threatening [7].

The study of the relationship between anthroposomatotypological features of man and the course of disease is undoubtedly an important step in the development of modern medicine. There are numerous data in the scientific and literature on the course of diseases of the respiratory system, cardiovascular and nervous system, gastrointestinal tract, etc., depending on the characteristics of anthropo-somatotypological indicators [21]. However, there is virtually no such work on the course of nephropathy, angiopathy, retinopathy and neuropathy in T1D. Identification of these patterns is a valuable contribution to the early diagnosis of these complications of T1D [13].

Currently, preclinical markers of structural and functional changes in the kidneys, retina, blood vessels, nervous tissue, myocardium, and others are being actively searched for. As such markers, along with traditional methods of early biochemical diagnosis, the definition of cystatin $C$ is proposed. Cystatin $\mathrm{C}$ is a low molecular weight protein with a molecular weight of $13.4 \mathrm{kDa}$, belongs to the family of cysteine proteinase inhibitors. An increase in serum cystatin $\mathrm{C}$ is observed with a decrease in renal filtration function, and an increase in its urinary excretion indicates dysfunction of proximal tubular cells [11].

Serum cystatin $\mathrm{C}$, an alternative marker of renal function, both alone and in combination with serum creatinine and/ or albuminuria, has recently been shown to be a better predictor of adverse effects compared to serum creatinine [15]. This protein is found in almost all human tissues and body fluids, which, unlike creatinine, is less susceptible to age, race or muscle mass. Studies have shown that elevated levels of cystatin $C$ are associated with the severity of retino-, angio- and neuropathy and are an independent risk factor for these complications along with the duration of diabetes and glycosylated hemoglobin levels [4].

The patterns described above were obtained mainly in the study of foreign samples. If confirmed in the domestic population, such an approach may change clinical practice and serve as a basis for the inclusion of cystatin $\mathrm{C}$ as a marker to improve the stratification of the risk of neuropathy, angiopathy and retinopathy in people with diabetic nephropathy. This group of high-risk individuals can benefit from more careful monitoring and more timely intervention before irreversible and threatening complications occur.

The aim of the study was to study the frequency of angio-, retino- and neuropathy, as well as the differences in general clinical and anthropometric parameters in patients with T1D with different levels of albumin in the urine depending on the level of cystatin $\mathrm{C}$.

\section{Materials and methods}

The sample consisted of 78 men and 62 women aged 22-26 years, patients with T1D, who underwent inpatient treatment in the therapeutic departments №1 and №2 of the Vinnytsia Regional Highly Specialized Endocrinology Center. The control group consisted of 8 practically healthy men and 13 practically healthy women of the same age.

All patients underwent the procedure of determining the level of microalbuminuria and cystatin $C$ by enzymelinked immunosorbent assay using spectrophotometry (reagents from ORGenTec, Germany). Regulatory values of microalbumin in the set of reagents used - 0-25 $\mu \mathrm{g} / \mathrm{ml}$.

Diagnosis of vascular lesions of the lower extremities was performed by determining the pulsation of the vessels of the lower extremities and the patient's subjective complaints of intermittent claudication, pain in the legs while walking, feeling cold in feet.

The condition of the vessels of the fundus was assessed by an ophthalmologist after medical dilation of the pupils using direct ophthalmoscopy. In order to diagnose diabetic retinopathy, the classification of $E$. Kohner, M. Porte (1992) was used: Stage I - non- 
proliferative, Stage II - preproliferative, Stage III - proliferative.

Diabetic neuropathy was diagnosed by a neurologist in the presence of characteristic subjective sensations in patients, as well as based on the signs of impaired sensitivity or reduction/loss of tendon reflexes detected as a result of objective neurological examination.

Blood pressure was measured on the arteria brachialis according to the method of Korotkov (1905), according to the recommendations of EHS experts (2007). ECG recording was performed according to the generally accepted method in 12 standard leads using a diagnostic automated system.

Anthropometric research included the determination of length, weight, body surface area, waist circumference and calculation of body mass index (the ratio of body weight in kilograms to height in meters squared). Body length was determined using a height meter (accuracy - up to $0.01 \mathrm{~m}$ ) when the shoes were removed. Body weight was measured using medical scales (accuracy - up to $0.5 \mathrm{~kg}$ ) without outer clothing in the morning. Waist circumference was measured with a centimeter tape.

Statistical data processing was performed in the license package "Statistica 5.5" using non-parametric methods of evaluation of the obtained results.

\section{Results}

Among patients with normoalbuminuria and cystatin $\mathrm{C}$ level $>0.9$, a higher $(p=0.059)$ percentage of men without angiopathy and a lower $(p=0.075)$ percentage with grade 3 angiopathy were found compared to women $(37.5 \%$ and $7.7 \%$ and $12.5 \%$ and $38.5 \%$ respectively).

When comparing the frequency of absence or presence of angiopathy between men with different albumin levels, in whom the level of cystatin $C$ was $<0.9$, a lower $(p<0.05)$ percentage with grade 3 angiopathy in the group with normoalbuminuria compared with proteinuria $(12.5 \%$ and $50.0 \%$, respectively) was found.

When comparing the frequency of absence or presence of angiopathy between men or women with different albumin levels, in which the level of cystatin $C$ was $>0.9$, found: in men - a higher $(p=0.056)$ percentage with no angiopathy in the group with normoalbuminuria compared with microalbuminuria (respectively $37.5 \%$ and $0 \%$ ); lower $(p=0.054)$ percentage with grade 3 angiopathy in the group with normoalbuminuria compared with microalbuminuria $(12.5 \%$ and $38.9 \%$, respectively); in women - a higher $(p=0.065)$ percentage with grade 2 angiopathy in the group with microalbuminuria compared with proteinuria $(75.0 \%$ and $28.6 \%$, respectively); lower $(p<0.05)$ percentage with grade 3 angiopathy in the group with microalbuminuria compared with proteinuria ( $16.7 \%$ and $71.4 \%$, respectively).

Among patients with microalbuminuria and cystatin $C<0.9$, a higher $(p=0.085)$ percentage of men with grade 3 retinopathy was found compared to women of the same group $(71.4 \%$ and $27.3 \%$, respectively). Among patients with normoalbuminuria and cystatin $\mathrm{C}>0.9$, a lower $(p=0.086)$ percentage of men with grade 3 retinopathy was found compared to women ( $4.2 \%$ and $23.1 \%$, respectively).

Among men with microalbuminuria and retinopathy of the 3rd degree, a higher $(p=0.058)$ percentage of patients with cystatin $\mathrm{C}$ level $<0.9$ was found in comparison with patients with cystatin $\mathrm{C}$ level $>0.9(71.4 \%$ and $27.8 \%$, respectively). Among women with normoalbuminuria and grade 3 retinopathy, a lower $(p<0.05)$ percentage of patients with cystatin $\mathrm{C}<0.9$ was found compared to patients with cystatin $\mathrm{C}>0.9$ ( $0 \%$ and $23.1 \%$, respectively). Among women with microalbuminuria and without retinopathy, a lower $(p=0.062)$ percentage of patients with cystatin $C$ level $<0.9$ was found compared to patients with cystatin $\mathrm{C}$ level $>0.9$ (18.2\% and $58.3 \%$, respectively).

When comparing the frequency of absence or presence of retinopathy between men or women with different albumin levels, in which the level of cystatin $C$ was $<0.9$, it was found: in men - a higher $(p<0.01-0.001)$ percentage without retinopathy in the group with normoalbuminuria compared with microalbuminuria and protein (respectively $75.0 \%, 0 \%$ and $0 \%)$; a higher $(p=0.092)$ percentage with grade 1 retinopathy in the group with microalbuminuria compared with proteinuria $(28.6 \%$ and $0 \%$, respectively); higher $(p<0.001$ in both cases) percentage with grade 2 retinopathy in the group with proteinuria compared with normoalbuminuria and microalbuminuria $(100 \%, 0 \%$ and $0 \%$, respectively); higher ( $p<0.01$ in both cases) percentage with grade 3 retinopathy in the group with microalbuminuria compared with normoalbuminuria and proteinuria $(71.4 \%$, $12.5 \%$ and $0 \%$, respectively); in women - a higher $(p<0.05)$ percentage without retinopathy in the group with normoalbuminuria compared with microalbuminuria $(61.1 \%$ and $18.2 \%$, respectively); a higher $(p<0.05)$ percentage with grade 3 retinopathy in the group with microalbuminuria compared with normoalbuminuria $(27.3 \%$ and $0 \%$, respectively).

When comparing the frequency of absence or presence of retinopathy between men or women with different albumin levels, in which the level of cystatin $C$ was $>0.9$, it was found: in men - a higher $(p<0.05)$ percentage without retinopathy in the group with normoalbuminuria compared with microalbuminuria $(66.7 \%$ and $27.8 \%)$; higher $(p<0.05)$ percentage with grade 3 retinopathy in the group with microalbuminuria compared with normoalbuminuria $(27.8 \%$ and $4.2 \%$, respectively); in women - a higher $(p=0.078)$ percentage without retinopathy in the group with microalbuminuria compared with proteinuria $(58.3 \%$ and $14.3 \%$, respectively); higher $(p<0.001)$ percentage with grade 2 retinopathy in the group with proteinuria compared with normoalbuminuria and microalbuminuria $(85.7 \%, 0 \%$ and $0 \%$, respectively).

When comparing the frequency of absence or presence of neuropathy between men or women with different albumin levels, in which the level of cystatin $C$ was $<0.9$, men found a higher $(p<0.001$ in both cases) percentage with grade 2 neuropathy in the group with normoalbuminuria and 
microalbuminuria compared with proteinuria $(75.0 \%, 100 \%$, and $0 \%$, respectively) and a lower ( $p<0.001$ in both cases) percentage with grade 3 neuropathy in the group with normoalbuminuria and microalbuminuria compared with proteinuria $(0 \%, 0 \%$, and $90.0 \%$, respectively).

When comparing the frequency of absence or presence of neuropathy between men or women with different albumin levels in which the level of cystatin $C$ was $>0.9$, it was found: in men - a lower $(p<0.05)$ percentage with grade 2 neuropathy in the group with normoalbuminuria compared with microalbuminuria (respectively $58.3 \%$ and $88.9 \%$ ); in women - a higher $(p<0.01$ and $p<0.001)$ percentage with grade 2 neuropathy in the group with normoalbuminuria and microalbuminuria compared with proteinuria $(76.9 \%$, $91.7 \%$ and $14.3 \%$, respectively); lower $(p<0.001)$ percentage with grade 3 neuropathy in the group with normoalbuminuria and microalbuminuria compared with proteinuria $(0 \%, 0 \%$ and $71.4 \%$, respectively).

Patients with microalbuminuria and cystatin $C$ level $>0.9$ had a higher $(p<0.05)$ value of this indicator compared with women of the same comparison group (119.2 \pm 13.0 and 109.6 \pm 13.2 , respectively).

The average value of systolic blood pressure in healthy men $(110.6 \pm 5.6)$ was lower $(p<0.05 ; p<0.05$ and $p=0.062)$

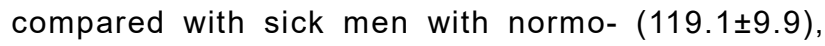
microalbuminuria $(120.3 \pm 12.7)$ and proteinuria $(124.0 \pm 16.5)$, in which the level of cystatin $C$ was $<0.9$. Healthy women had lower $(p<0.05$ in both cases) mean systolic blood pressure $(110.4 \pm 9.7)$ compared with sick women with normoalbuminuria $(119.4 \pm 11.0)$ and microalbuminuria $(122.7 \pm 12.9)$, in whom the level of cystatin $C$ was $<0.9$.

The average value of systolic blood pressure in healthy men $(110.6 \pm 5.6)$ was lower $(p<0.05$ and $p<0.01)$ in comparison with sick men with normo- $(116.3 \pm 7.8)$ and microalbuminuria $(119.2 \pm 13.0)$, in whom the level of cystatin $C$ was $>0.9$. Healthy women had a lower $(p<0.001)$ mean systolic blood pressure $(110.4 \pm 9.7)$ compared to sick women with proteinuria $(137.1 \pm 7.0)$, in whom the level of cystatin $C$ was $>0.9$.

In patients with proteinuria in whom the level of cystatin $C$ was $>0.9$, found a higher $(p<0.01$ and $p<0.001)$ average systolic blood pressure $(137.1 \pm 7.0)$ compared with patients with normoalbuminuria $(113.5 \pm 11.1)$ and microalbuminuria (109.6 \pm 13.2$)$.

Women with microalbuminuria with cystatin $\mathrm{C}<0.9$ had a lower $(p<0.05)$ mean systolic blood pressure compared to women with microalbuminuria with cystatin $C$ level $>0.9$ (122.7 \pm 12.9 and $137.1 \pm 7.0$, respectively).

Patients with microalbuminuria and cystatin C level $>0.9$ had a higher $(p<0.05)$ value of this indicator compared to women of the same comparison group $(75.56 \pm 8.20$ and $68.33 \pm 8.35$, respectively).

There was a lower $(p<0.01)$ mean value of diastolic blood pressure in healthy men $(68.75 \pm 5.60)$ compared with sick men with proteinuria $(79.00 \pm 6.99)$, in whom the level of cystatin $C$ was $<0.9$. Patients with proteinuria with cystatin
$\mathrm{C}<0.9$ had a higher $(\mathrm{p}<0.05)$ mean diastolic blood pressure

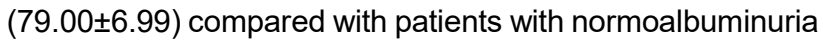

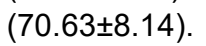

Healthy women had lower ( $p<0.01$ in both cases) mean diastolic blood pressure $(66.15 \pm 5.83)$ compared to sick

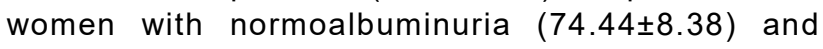
microalbuminuria $(76.36 \pm 7.10)$, in whom the level of cystatin C was $<0.9$.

The mean value of diastolic blood pressure in healthy men $(68.75 \pm 3.54)$ was lower $(p<0.01)$ compared with sick men with normo- $(71.67 \pm 6.20)$ and microalbuminuria (75.56 \pm 8.20$)$, in whom the level of cystatin $C$ was $>0.9$. Patients with microalbuminuria with cystatin $\mathrm{C}>0.9$ had a higher $(p<0.05)$ mean diastolic blood pressure $(75.56 \pm 8.20)$ compared with patients with normoalbuminuria (71.67 \pm 6.20$)$. In healthy women, the average value of diastolic blood pressure $(66.15 \pm 5.83)$ was lower $(p<0.05$ and $p<0.001)$ compared with sick women with normoalbuminuria $(73.08 \pm 6.93)$ and proteinuria $(84.29 \pm 5.35)$, in whom the level of cystatin $C$ was $>0.9$. Patients with proteinuria with cystatin $\mathrm{C}>0.9$ had a higher $(p<0.01$ in both cases) mean diastolic blood pressure value $(84.29 \pm 5.35)$ compared with patients with normoalbuminuria (73.08 \pm 6.93$)$ and microalbuminuria $(68.33 \pm 8.35)$.

Women with microalbuminuria with cystatin $\mathrm{C}<0.9$ had a lower $(p<0.05)$ mean diastolic blood pressure value compared to women with microalbuminuria with cystatin C>0.9 (76.36 \pm 7.10 and 84.29 \pm 5.35 , respectively).

Patients with microalbuminuria and cystatin $C<0.9$ had a higher $(p=0.070)$ heart rate compared to women in the same comparison group $(88.86 \pm 8.20$ and $78.73 \pm 11.00$, respectively).

There was a lower $(p<0.01)$ mean heart rate in healthy men $(72.50 \pm 5.73)$ compared with sick men with microalbuminuria $(88.86 \pm 9.92)$ and proteinuria $(83.0 \pm 8.81)$, in whom the level of cystatin $C$ was $<0.9$. Patients with microalbuminuria with cystatin $C>0.9$ had a higher $(p<0.05)$ mean heart rate $(88.86 \pm 9.92)$ compared with patients with normoalbuminuria $(76.31 \pm 11.32)$.

Healthy women had a lower $(p=0.052)$ mean heart rate $(71.54 \pm 5.50)$ compared to sick women with microalbuminuria $(78.73 \pm 11.00)$, in whom the level of cystatin $C$ was $<0.9$.

There was a lower $(p<0.05)$ mean heart rate in healthy men (72.50 \pm 5.73$)$ compared with sick men with microalbuminuria $(82.39 \pm 12.10)$, in whom the level of cystatin $\mathrm{C}$ was $>0.9$. Patients with microalbuminuria with cystatin $C>0.9$ had a higher $(p<0.05)$ mean heart rate $(82.39 \pm 12.10)$ compared with patients with normoalbuminuria $(75.00 \pm 9.29)$. Healthy women had lower $(p=0.065, p<0.01$ and $p<0.001)$ mean heart rate $(71.54 \pm 5.50)$ compared to sick women with normoalbuminuria $(79.54 \pm 10.90)$, microalbuminuria $(85.42 \pm 13.57)$ and proteinuria $(95.71 \pm 4.96)$, in which the level of cystatin $C$ was $>0.9$. In patients with proteinuria, in whom the level of cystatin $C>0.9$, found a higher $(p<0.01$ and $p=0.091)$ mean heart rate $(95.71 \pm 4.96)$ compared with 
patients with normoalbuminuria $(79.54 \pm 10.90)$ and microalbuminuria (85.42 \pm 13.57$)$.

Men with microalbuminuria with cystatin C level $<0.9$ had a higher $(p<0.05)$ mean heart rate value compared with men with microalbuminuria with cystatin $\mathrm{C}>0.9$ $(88.86 \pm 9.92$ and $82.39 \pm 12.10$, respectively).

Healthy men had higher $(p<0.001)$ body length values compared to healthy women $(183.5 \pm 3.0$ and $165.7 \pm 3.5$, respectively). A higher body length was found in patients with normoalbuminuria $(177.2 \pm 7.1 ; p<0.001)$ and microalbuminuria $(172.0 \pm 11.4 ; p=0.085)$ with cystatin $\mathrm{C}<0.9$ compared to women in the same comparison group (162.7 \pm 5.5 and $162.5 \pm 6.1$, respectively). A greater value of body length was observed in patients with normoalbuminuria $(174.4 \pm 6.0 ; p<0.001)$ and microalbuminuria $(171.1 \pm 6.1$; $\mathrm{p}<0.001$ ) with cystatin $\mathrm{C}$ level $>0.9$ compared to women of the same comparison group $(161.5 \pm 6.1$ and $160.8 \pm 7.9$, respectively).

Healthy men had a higher $(p<0.05-0.01)$ mean body length $(183.5 \pm 3.0)$ compared with sick men with normoalbuminuria (177.2 \pm 7.1$)$, microalbuminuria

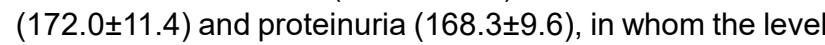
cystatin $\mathrm{C}$ was $<0.9$. Patients men with proteinuria in whom the level of cystatin $C$ was $<0.9$ had a lower $(p<0.05)$ mean body length $(168.3 \pm 9.6)$ compared with patients with

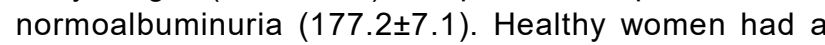
higher $(p=0.056)$ mean body length $(165.7 \pm 3.5)$ compared with sick women with microalbuminuria $(162.5 \pm 6.1)$, in whom the level of cystatin $C$ was $<0.9$.

Healthy men had a higher ( $p<0.001$ in both cases) mean body length $(183.5 \pm 3.0)$ compared with sick men with normoalbuminuria $(174.4 \pm 6.0)$ and microalbuminuria (171.0 \pm 6.1 ), in whom the level of cystatin $C$ was $>0.9$. Patients with microalbuminuria with cystatin $\mathrm{C}>0.9$ had a lower $(p<0.05)$ mean body length $(171.0 \pm 6.1)$ compared with patients with normoalbuminuria $(174.4 \pm 6.0)$. Healthy women had higher $(p=0.055$ and $p<0.05)$ mean body length $(165.7 \pm 3.5)$ compared with sick women with normoalbuminuria $(160.8 \pm 7.9)$ and proteinuria $(158.9 \pm 7.6)$, in whom the level of cystatin $C$ was $<0.9$.

Healthy men had higher $(p<0.001)$ body weight values compared to healthy women $(83.13 \pm 4.05$ and $60.46 \pm 3.18$, respectively). A higher body weight was found in patients with normoalbuminuria $(77.41 \pm 9.99 ; p<0.05)$ with cystatin C level $<0.9$ compared with women in the same comparison group (66.75 \pm 12.85 , respectively). A higher value of this indicator was observed in patients with normoalbuminuria (75.46 $\pm 10.46 ; \quad p<0.001)$ and microalbuminuria (66.31 \pm 12.59 ; $p=0.069$ ) with cystatin $C>0.9$ compared to women of the same comparison group $(60.23 \pm 9.75$ and $57.75 \pm 10.23$, respectively).

Healthy men had higher $(p<0.05$ and $p<0.001)$ mean body weight $(83.13 \pm 4.05)$ compared with sick men with microalbuminuria $(73.21 \pm 15.67)$ and proteinuria $(63.90 \pm 7.37)$, in whom the level of cystatin $C$ was $<0.9$. In patients with proteinuria, in whom the level of cystatin $C$ was $<0.9$, found a lower $(p<0.01)$ average value of this indicator $(63.90 \pm 7.37)$ compared with patients with normoalbuminuria $(77.41 \pm 9.99)$.

Healthy men had a higher $(p<0.05$ and $p<0.01)$ mean body weight $(83.13 \pm 4.05)$ compared with sick men with normoalbuminuria $(75.46 \pm 10.46)$ and microalbuminuria $(66.31 \pm 12.59)$, in whom the level of cystatin $C$ was $>0.9$. Patients with microalbuminuria with cystatin $C$ level $>0.9$ had a lower $(p<0.05)$ mean value $(66.31 \pm 12.59)$ compared with patients with normoalbuminuria $(75.46 \pm 10.46)$.

Women with microalbuminuria with cystatin $\mathrm{C}$ level $<0.9$ had a higher $(p<0.05)$ mean body weight compared with women with microalbuminuria with cystatin $\mathrm{C}$ level $>0.9$ (71.18 \pm 16.49 and $57.75 \pm 10.23$, respectively).

Healthy men had higher $(p<0.001)$ body surface area compared to healthy women $(2.056 \pm 0.048$ and $1.671 \pm 0.057$, respectively). A larger value of body surface area was found in patients with normoalbuminuria $(1.944 \pm 0.137$; $p<0.001)$ with the level of cystatin $C<0.9$ compared with women of the same comparison group (respectively 1.712 \pm 0.162 ). A higher value of this indicator was observed in patients with normoalbuminuria $(1.900 \pm 0.148 ; p<0.001)$ and microalbuminuria $(1.769 \pm 0.164 ; p<0.01)$ with cystatin $C>0.9$ compared to women in the same comparison group (respectively $1.632 \pm 0.120$ and $1.598 \pm 0.159$ ).

In healthy men, higher $(p=0.054, p<0.05$ and $p<0.001)$ average body surface area $(2.056 \pm 0.048)$ was found compared with sick men with normoalbuminuria (1.944 \pm 0.137$)$, microalbuminuria $(1.856 \pm 0.238)$ and proteinuria $(1.729 \pm 0.147)$, in which the level of cystatin C was $<0.9$. Patients with proteinuria in whom the level of cystatin $C$ was $<0.9$, had a lower $(p<0.01)$ average value of this indicator $(1.729 \pm 0.147)$ compared with patients with normoalbuminuria $(1.944 \pm 0.137)$.

In healthy men, a higher $(p<0.01$ and $p<0.001)$ mean body surface area $(2.056 \pm 0.048)$ was found compared with sick men with normoalbuminuria $(1.900 \pm 0.148)$ and microalbuminuria $(1.769 \pm 0.164)$, in whom the level of cystatin $\mathrm{C}$ was $>0.9$. Patients with microalbuminuria with cystatin $C>0.9$ had a lower $(p<0.05)$ mean value $(1.769 \pm 0.164)$ compared with patients with normoalbuminuria $(1.900 \pm 0.148)$. In healthy women, a higher $(p=0.096)$ mean value of body surface area $(1.671 \pm 0.057)$ was found in comparison with sick women with normoalbuminuria $(1.632 \pm 0.120)$, in whom the level of cystatin $\mathrm{C}$ was $>0.9$.

In women with microalbuminuria, in whom the level of cystatin $C$ was $<0.9$, the average value was higher $(p=0.062)$ compared with women with microalbuminuria, in whom the level of cystatin $C$ was $>0.9$ (respectively $1.758 \pm 0.209$ and $1.598 \pm 0.159)$.

Healthy men had higher $(p<0.001)$ waist circumference values compared to healthy women $(78.25 \pm 1.39$ and $67.69 \pm 3.04$, respectively). A higher waist circumference was found in patients with normoalbuminuria $(81.31 \pm 5.06$; $\mathrm{p}<0.05$ ) with cystatin $\mathrm{C}<0.9$ compared to women in the 
same comparison group (76.22 \pm 8.48 , respectively). A higher value of this indicator was observed in patients with men with microalbuminuria $(74.44 \pm 6.23 ; p<0.05)$ with $a$ level of cystatin $\mathrm{C}>0.9$ compared with women in the same comparison group (respectively $70.42 \pm 4.96$ ).

In healthy men, the mean value of waist circumference $(78.25 \pm 1.39)$ was lower $(p=0.062)$ compared with sick men with normoalbuminuria $(81.31 \pm 5.06)$ and higher $(p=0.064$ and $p=0.051)$ compared with microalbuminuria $(77.29 \pm 10.45)$ and proteinuria $(74.40 \pm 4.35)$, in which the level of cystatin $C$ was $<0.9$. In patients with proteinuria, in whom the level of cystatin $C$ was $<0.9$, found a lower $(p<0.05$ and $p<0.01)$ average value of this indicator $(74.40 \pm 4.35)$ compared with patients with normoalbuminuria

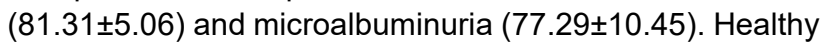
women had a lower ( $p<0.01$ in both cases) average waist circumference $(67.69 \pm 3.04)$ compared to sick women with normoalbuminuria $(76.22 \pm 8.48)$ and microalbuminuria (75.82 \pm 8.05$)$.

In healthy men, a higher $(p<0.01)$ average value of waist circumference $(78.25 \pm 1.39)$ was found in comparison with sick men with microalbuminuria $(74.44 \pm 6.23)$, in whom the level of cystatin $C$ was $>0.9$. Patients with microalbuminuria with cystatin $C>0.9$ had a lower $(p<0.05)$ mean value (74.44 \pm 6.23$)$ compared with patients with normoalbuminuria $(79.29 \pm 8.24)$. Healthy women had a lower $(p<0.05$ in both cases) average waist circumference $(67.69 \pm 3.04)$ compared to sick women with normoalbuminuria $(74.92 \pm 8.34)$ and proteinuria (72.00 \pm 4.40$)$, in whom the level of cystatin $C$ was $>0.9$.

Women with microalbuminuria with cystatin $\mathrm{C}<0.9$ had a higher $(p<0.05)$ average waist circumference compared with women with microalbuminuria with cystatin $\mathrm{C}>0.9$ (75.82 \pm 8.05 and 70.42 \pm 4.96 , respectively).

Healthy men had higher $(p<0.001)$ body mass index values compared to healthy women $(24.69 \pm 1.40$ and $22.02 \pm 0.96$, respectively). A higher value of this indicator was observed in patients with normoalbuminuria $(24.60 \pm 2.51 ; p=0.095)$ with a level of cystatin $C>0.9$ compared with women in the same comparison group (respectively $23.52 \pm 3.99$ ).

Healthy men had higher $(p<0.001)$ body mass index values compared to healthy women $(24.69 \pm 1.40$ and $22.02 \pm 0.96$, respectively). A higher value of this indicator was observed in patients with normoalbuminuria $(24.60 \pm 2.51 ; p=0.095)$ with a level of cystatin $C>0.9$ compared with women in the same comparison group (respectively $23.52 \pm 3.99$ ).

In healthy men, a higher $(p<0.05)$ mean value of the body mass index was found $(24.69 \pm 1.40)$ compared with sick men with proteinuria $(22.51 \pm 1.62)$, in whom the level of cystatin $\mathrm{C}<0.9$. In patients with proteinuria, in whom the level of cystatin $C<0.9$, the average value of this indicator was lower $(p=0.087)(22.51 \pm 1.62)$ compared with patients with normoalbuminuria $(24.36 \pm 2.76)$. Healthy women had a lower $(p<0.05$ in both cases) mean body mass index
(22.02 \pm 0.94$)$ compared with sick women with normoalbuminuria $(24.96 \pm 4.02)$ and microalbuminuria (26.75 \pm 4.93$)$.

Patients men with microalbuminuria with cystatin $C>0.9$ had a lower $(p=0.055)$ mean value $(22.56 \pm 4.16)$ compared with patients with normoalbuminuria $(24.60 \pm 2.51)$. In healthy women, a lower $(p<0.05)$ mean value of the body mass index $(22.02 \pm 0.94)$ was found in comparison with sick women with proteinuria $(23.73 \pm 2.38)$, in whom the level of cystatin $\mathrm{C}$ was $>0.9$.

In women with microalbuminuria, in whom the level of cystatin $C$ was $<0.9$, the average value of the body mass index was higher $(p<0.05)$ compared to women with microalbuminuria, in whom the level of cystatin $C$ was $>0.9$ (26.75 \pm 4.93 and $22.41 \pm 3.07$, respectively).

\section{Discussion}

Because macro- and microvascular complications of T1D are better treated in the early stages, the problem of using markers that are more effective than determining urinary albumin excretion is very relevant. Such a marker is thought to be cystatin $C$. Measurement of serum cystatin $C$ levels may be useful for screening for mild to moderate stages of diabetic angio-, retino-, nephro-, and neuropathy. An increase in its level indicates that the lesions of the target organs are progressing [2].

In a pairwise comparison of groups of men or women who took into account the level of cystatin $C$, with the corresponding sex groups of subjects, in which this biochemical indicator was not taken into account, found similar patterns and trends [12]. Thus, in the group of men with cystatin $C$ levels $<0.9$ and in women with cystatin $C$ levels $>0.9$, the percentage of patients with severe microvascular complications of diabetes increased with increasing albuminuria.

According to scientific studies, an increase in serum cystatin $C$ in the absence of patients with T1D microalbuminuria should be regarded as a predictor of the formation of its complications [19]. Therefore, the focus of our study was on comparing the percentage of patients in groups with different degrees of diabetic complications at a level of less than and greater than 0.9.

There was a significantly lower percentage of patients with cystatin $\mathrm{C}$ level $<0.9$ compared with patients with cystatin C level $>0.9$ among groups of men with microalbuminuria and retinopathy of the 3rd degree and women with normoalbuminuria and retinopathy of the 3rd degree, with microalbuminuria and without retinopathy. In addition to sex differences, it is noteworthy that only in the case of retinopathy, the percentage of patients "responds" to the gradation of cystatin C. According to medical and epidemiological studies, retinopathy develops (or rather clinically manifested) earlier than complications such as neuro- and angiopathy, its initial manifestations are correlated with the appearance of microalbuminuria [8]. Unfortunately, it was not possible to compare a similar 
picture in the groups with proteinuria, as in women with cystatin $\mathrm{C}<0.9$ and men with cystatin $\mathrm{C}>0.9$, the number of observations was only 1 and 3 people, respectively.

Hypertension is an important risk factor for the development of many serious complications of T1D and its deterioration, including diabetic retinopathy, nephropathy, micro- and macroangiopathy [1]. Diabetes mellitus itself is also a factor in the development of arterial hypertension, because in this endocrine pathology there is damage to arteries and, especially, small arteries - arterioles, which contributes to the deposition of atherosclerotic plaques in them [3]. When glycemia decompensates, the body increases the level of contrainsular hormones - adrenaline, norepinephrine, thyroxine, cortisol. Elevated adrenergic background is manifested by tachycardia and hypertension [16]. Another explanation is that the parasympathetic nervous system in diabetes is affected earlier than the sympathetic, so the initial sign of autonomic neuropathy may be resting tachycardia [6].

Examination of the general population revealed that cystatin $\mathrm{C}$ levels were positively associated with hypertension and pulse. Scientists believe that there are significant differences between filtration in healthy and T1D and believe that serum cystatin $\mathrm{C}$ reliably reflects the glomerular filtration rate in these categories of individuals [10].

In our study, in patients with T1D compared with the control group, the value of systolic blood pressure was significantly higher (respectively, in men with normo-, microalbuminuria and proteinuria by $7.14 \%, 8.1 \%$ and $10.8 \%$; in women with normo-, microalbuminuria -7.5 and $10.0 \%$ (cystatin $\mathrm{C}<0.9$ ); in men with normo-, microalbuminuria - by $4.9 \%$ and $7.2 \%$; in women with proteinuria - by $19.5 \%$ (cystatin C>0.9) and increases with increasing albumin levels in the urine.

In patients with T1D compared with the control group, the value of diastolic blood pressure is also significantly higher (respectively in men with proteinuria by $13.0 \%$; in women with normo-, microalbuminuria - by $11.4 \%$ and $13.4 \%$ (cystatin $\mathrm{C}<0.9$ ); in men with microalbuminuria - by $9.0 \%$; in women with normo- and proteinuria - by $9.5 \%$ and $21.5 \%$ (cystatin $\mathrm{C}>0.9$ ) and increases with increasing albumin levels in the urine.

Regarding the pulse, a similar pattern was observed its value in patients with T1D is significantly higher than in healthy subjects and increases synchronously with an increase in urinary albumin levels (respectively in men with microalbuminuria and proteinuria by $18.4 \%$ and $12.6 \%$; in women with microalbuminuria - by $9.13 \%$ (cystatin $\mathrm{C}<0.9$ ); in men with microalbuminuria - by $12.0 \%$; in women with normo-, microalbuminuria and proteinuria by $10.1 \%, 16.3 \%$ and $25.3 \%$ (cystatin $\mathrm{C}>0.9$ )).

Diastolic blood pressure in men with microalbuminuria was $5.2 \%$ higher than in men with normoalbuminuria (cystatin $\mathrm{C}>0.9$ ). The magnitude of the pulse is also higher in the first group of sick men compared with other (respectively by $14.1 \%$ (cystatin $\mathrm{C}<0.9$ ) and $8.9 \%$ (cystatin
C>0.9)).

In women, no comparison of similar differences in blood pressure and heart rate between similar groups was found. At the same time, between groups of women with normo-, microalbuminuria (cystatin $\mathrm{C}>0.9$ ) such differences are significant. Thus, in women with proteinuria compared with normo-, microalbuminuria systolic pressure values are higher by $17.2 \%$ and $20.1 \%$, respectively; diastolic pressure - by $13.3 \%$ and $18.9 \%$; heart rate - by $16.9 \%$ and $10.6 \%$.

Shulkina S.G. and Smirnova O.M. [19] proved that the value of blood pressure has direct correlations with the level of cystatin $\mathrm{C}$. Thus, with increasing systolic and diastolic pressure, there should be an increase in this biochemical indicator. Thus, in women with microalbuminuria and cystatin $\mathrm{C}$ level $>0.9$ systolic pressure is lower by $12.0 \%$, and diastolic - by $11.8 \%$ compared with patients with cystatin $\mathrm{C}$ level $<0.9$. In men with microalbuminuria and cystatin $C$ levels $>0.9$, the pulse was lower by $7.9 \%$ compared with men with cystatin $C$ levels $<0.9$.

A sufficient amount of information has been accumulated on the relationship between the clinical course and the peculiarities of susceptibility to different types of diseases of persons of different somatotypes. Thus, among asthenics, the most common diseases are varicose veins, gastritis, hypotension, chronic adrenal insufficiency and T1D in particular [14].

A number of scientists in a study of people with T1D, found that they are characterized by lower body length, increased waist circumference and increased accumulation of abdominal fat. In women, low bone and muscle mass were found along with high fat mass. Men in all components had a moderately low weight $[5,17]$.

According to the results of our study in patients with T1D compared to the control group, the length of the body is significantly less (respectively in men with normo-, microalbuminuria and proteinuria by $3.6 \%, 6.7 \%$ and $9.0 \%$; in women with microalbuminuria - by $1.9 \%$ (cystatin $\mathrm{C}<0.9$ ); in men with normo-, microalbuminuria - by $5.2 \%$ and $7.3 \%$; in women with normoalbuminuria and proteinuria - by $2.6 \%$ and $4.3 \%$ (cystatin $\mathrm{C}>0.9$ )) and decreases with increasing levels of albumin in the urine.

Compared with the control group, patients with T1D had significantly lower body weight $(13.6 \%$ and $30.1 \%$, respectively, in men with microalbuminuria and proteinuria) and $10.2 \%$ and $25.4 \%$ in men with normo- and microalbuminuria (cystatin $\mathrm{C}>0.9$ )) and decreases with increasing albumin levels in the urine.

In patients with T1D compared to the control group, the size of the body surface area is also significantly smaller (respectively in men with normo-, microalbuminuria and proteinuria by $5.8 \%, 10.8 \%$ and $18.9 \%$ (cystatin $\mathrm{C}<0.9$ ); in men with normo- and microalbuminuria - by $8.2 \%$ and $16.2 \%$ (cystatin $\mathrm{C}>0.9$ )) and decreases with increasing albumin levels in the urine. 
Regarding waist circumference, the following pattern was observed - its value in patients with T1D and normoalbuminuria was significantly higher, and in patients of other groups significantly lower compared to healthy subjects (respectively, in men with normo-, microalbuminuria and proteinuria by $3.8 \%, 1.2 \%$ and $5.2 \%$ (cystatin $\mathrm{C}<0.9$ ); in men with microalbuminuria - by $5.1 \%$ (cystatin C>0.9)). Compared to healthy women, the waist circumference was higher in sick women $(11.2 \%$ and $10.7 \%$, respectively in women with normo- and microalbuminuria (cystatin $\mathrm{C}<0.9$ ); $9.7 \%$ and $6.0 \%$ in women with normo- and proteinuria (cystatin C>0.9)).

In men with T1D and proteinuria compared with the control group, the value of the body mass index was significantly lower by $9.7 \%$ (cystatin $\mathrm{C}<0.9$ ). The value of the body mass index was significantly higher in patients with normoalbuminuria and microalbuminuria - by $11.8 \%$ and $17.7 \%$ (cystatin $\mathrm{C}<0.9$ ), respectively, and in patients with proteinuria by $7.2 \%$ (cystatin $\mathrm{C}>0.9$ ) compared with healthy women. In men with microalbuminuria, the value of the body mass index was $9.0 \%$ significantly lower than in men with normoalbuminuria (cystatin $\mathrm{C}>0.9$ ).

Summarizing the above-described regularities concerning the features of anthropometric parameters at different levels of cystatin $C$, it should be noted that in the case when cystatin $\mathrm{C}<0.9$, significant differences were found only for waist circumference in men with normoalbuminuria and microalbuminuria. When the level of cystatin $C$ is $>0.9$, in this group of men there are significant differences in all anthropometric parameters.

In early studies, it was concluded that serum cystatin C does not depend on anthropometric parameters [18]. However, then in a number of other studies found a small but significant positive correlation between the level of this biochemical indicator and body mass index, length and surface area of the body [9]. A similar trend was found for the general population [10]. When observing the Japanese sample (596 people aged $30-75$ years), it was shown that the level of cystatin $C$ is positively correlated with the amount of adipose tissue. More recently, a positive association between obesity and serum cystatin $C$ levels has also been established [19]. Moreover, there have been reports that $a$

\section{References}

[1] Abegaz, T. M., Abdela, O. A., Bhagavathula, A. S., \& Teni, F. S. (2018). Magnitude and determinants of uncontrolled blood pressure among hypertensive patients in Ethiopia: hospitalbased observational study. Pharmacy Practice (Granada), 16(2), 1173. doi: 10.18549/PharmPract.2018.02.1173

[2] Chawla, A., Chawla, R., \& Jaggi, S. (2016). Microvasular and macrovascular complications in diabetes mellitus: distinct or continuum? Indian Journal of Endocrinology and Metabolism, 20(4), 546-551. doi: 10.4103/2230-8210.183480

[3] Dedov, I. I. (2012). Diabetes mellitus: acute and chronic complications. Moscow: MIA.

[4] Duh, E. J., Sun, J. K., \& Stitt, A. W. (2017). Diabetic retinopathy: current understanding, mechanisms, and treatment strategies. JCl insight, 2(14), e93751. doi: 10.1172/jci.insight.93751 significantly elevated body mass index may affect serum cystatin C levels [20].

In women with microalbuminuria and cystatin $C$ level $<0.9$, significantly higher values of the following anthropometric indicators were found in comparison with women in whom cystatin C>0.9: body weight - by $23.2 \%$; body surface area - by $4.9 \%$; waist circumference - by $7.7 \%$; body mass index - by $19.4 \%$.

In our study, unfortunately, it was not possible to conduct a complete analysis of changes in general clinical and anthropometric parameters in patients with albuminuria at different levels of cystatin $C$, because the distribution in groups with proteinuria did not analyze women with cystatin $\mathrm{C}<0.9$ and men with cystatin $\mathrm{C}>0.9$ (the number of observations in these groups was only 1 and 3 , respectively). For this reason, there is a limited explanation of why between patients with microalbuminuria, at different levels of cystatin $C$ there are higher values of general clinical and anthropometric indicators at lower levels, while these indicators in general groups are characterized by diametrically opposite patterns (the value of these indicators increased as the level of albumin in the urine increases) [12].

Thus, the level of cystatin $\mathrm{C}$ may predict the risk of complications of diabetes and signal the "preclinical" phase of renal dysfunction. Terms similar to preclinical kidney disease - prehypertension, preneuropathy, preretinopathy, etc.

\section{Conclusions}

1. In the group of subjects in which cystatin $C$ was taken into account, and in the general group (excluding cystatin $\mathrm{C}$ ) there were common tendencies to increase the degree of retino-, angio- and neuropathy with increasing albumin levels in the urine. However, the percentage of those in the group with a more severe degree of these complications is higher when using this biochemical indicator, which avoids "blind zones" in the early diagnosis of complications of T1D.

2. Between healthy and patients with T1D with varying degrees of albuminuria found differences in general clinical and anthropometric parameters, and they are greater the higher the level of cystatin $\mathrm{C}$.

[5] Galić, B. S., Pavlica, T., Udicki, M., Stokić, E., Mikalački, M., Korovljev, D., ... Adamović, D. (2016). Somatotype characteristics of normal-weight and obese women among different metabolic subtypes. Archives of Endocrinology and Metabolism, 60(1), 60-65. doi: 10.1590/2359-3997000000159

[6] Grisanti, LA. (2018). Diabetes and arrhythmias: pathophysiology, mechanisms and therapeutic outcomes. Frontiers in Physiology, 9, 1669. doi: 10.3389/fphys.2018.01669

[7] Harding, J. L., Pavkov, M. E., Magliano, D. J., Shaw, J. E., \& Gregg, E. W. (2019). Global trends in diabetes complications: a review of current evidence. Diabetologia, 62(1), 3-16. doi: 10.1007/s00125-018-4711-2

[8] Klein, R., Knudtson, M. D., Lee, K. E., Gangnon, R., \& Klein, B. E. (2008). The Wisconsin Epidemiologic Study of Diabetic 
Retinopathy XXII: the twenty-five-year progression of retinopathy in persons with type 1 diabetes. Ophthalmology, 115(11), 1859-1868. doi: 10.1016/j.ophtha.2008.08.023

[9] Knight, E. L., Verhave, J. C., Spiegelman, D., Hillege, H. L., De Zeeuw, D., Curhan, G. C., \& De Jong, P. E. (2004). Factors influencing serum cystatin $\mathrm{C}$ levels other than renal function and the impact on renal function measurement. Kidney International, 65(4), 1416-1421. doi: 10.1111/j.15231755.2004.00517.x

[10] Köttgen, A., Selvin, E., Stevens, L. A., Levey, A. S., Van Lente, F., \& Coresh, J. (2008). Serum cystatin C in the united states: The third national health and nutrition examination survey (NHANES III). American Journal of Kidney Diseases, 51(3), 385-394. doi: 10.1053/j.ajkd.2007.11.019

[11] Krolewski, A. S., Warram, J. H., Forsblom, C., Smiles, A. M., Thorn, L., Skupien, J., ... Groop, P. H. (2012). Serum concentration of cystatin $\mathrm{C}$ and risk of end-stage renal disease in diabetes. Diabetes Care, 35(11), 2311-2316. doi: 10.2337/ dc11-2220

[12] Kryvoviaz, Yu. O. (2020). General clinical and anthropometric parameters in patients with type 1 diabetes mellitus depending on the level of albumin in the urine. Biomedical and Biosocial Anthropology, 38, 61-68. doi: 10.31393/bba38-2020-09

[13] Nikolenko, V. N., Nikityuk, D. B., \& Chava, S. V. (2013). Domestic constitutional anatomy in the aspect of personalized medicine. Sechenovsky Bulletin, (4 (14)), 9-17.

[14] Page-Reeves, J., Mishra, S. I., Niforatos, J., Regino, L., \& Bulten, R. (2013). An integrated approach to diabetes prevention: anthropology, public health, and community engagement. Qualitative report (Online), 18, 1-22. PMID:

\section{9}

[15] Pavkov, M. E., Knowler, W. C., Hanson, R. L., Williams, D. E., Lemley, K. V., Myers, B. D., \& Nelson, R. G. (2013). Comparison of serum cystatin $C$, serum creatinine, measured GFR, and estimated GFR to assess the risk of kidney failure in American Indians with diabetic nephropathy. American Journal of Kidney Diseases, 62(1), 33-41. doi: 10.1053/j.ajkd.2012.11.044

[16] Sampanis, C., \& Zamboulis, C. (2008). Arterial hypertension in diabetes mellitus: from theory to clinical practice. Hippokratia, 12(2), 74-80. PMID: 18923653

[17] Sénéchal, M., McGavock, J. M., Church, T. S., Lee, D. C., Earnest, C. P., Sui, X., \& Blair, S. N. (2014). Cut-points of muscle strength associated with metabolic syndrome in men. Medicine and science in sports and exercise, 46(8), 14751481. doi: 10.1249/MSS.0000000000000266

[18] Shlipak, M. G. (2007). Cystatin C as a marker of glomerular filtration rate in chronic kidney disease: influence of body composition. Nature Clinical Practice Nephrology, 3(4), 188189. doi: $10.1038 /$ ncpneph0404

[19] Shulkina, S. G., \& Smirnova, E. N. (2017). Diagnostic value of cystatin $\mathrm{C}$ and type IV collagen in patients with arterial hypertension and obesity. Arterial Hypertension, 23(6), 552560. doi: 10.18705/1607-419X-2017-23-6-552-560

[20] Senko, V. I., Okolokulak, E. S., \& Sidorovich, S. A. (2009). Features of the body type in persons with type 1 diabetes mellitus. Health and environmental issues, (2 (20)), 12-17.

[21] Zhmurik, V. V., Kuhar, I. D., \& Zhmurik, D. V. (2007). Features of anthropometric indicators and somatotype in the adult population with insulin-dependent diabetes mellitus. Reports of Morphology, 13(1), 157-162.

\section{ОСОБЛИВОСТІ ЧАСТОТИ АНГІО-, РЕТИНО- ТА НЕЙРОПАТІЇ, ЗАГАЛЬНОКЛІНІЧНИХ ТА АНТРОПОМЕТРИЧНИХ ПОКАЗНИКІВ У ХВОРИХ НА ЦУКРОВИЙ ДІАБЕТ 1 ТИПУ 3 РІЗНИМ РІВНЕМ АЛЬБУМІНУ В СЕЧІ В ЗАЛЕЖНОСТІ ВІД РІВНЯ ЦИСТАТИНУ С}

Кривов'яз Ю.О., Вернигородський В.С., Дзевульська І.В., Шевчук Ю.Г., Жученко П.С.

Цистатин С поліпшує стратифрікацію ризику серед осіб з діабетичною нефропатією щодо ризику смертності, серцевосудинних захворювань, порушень з боку органу зору і нервової системи на доклінічній і початковій стадії. Мета дослідження - вивчити частоту ангіо-, ретино- та нейропатії, а також відмінності загально-клінічних та антропометричних показників у хворих на цукровий діабет 1 типу (ЦД 1) з різним рівнем альбуміну в сечі в залежності від рівня цистатину С. Вибірка склала 78 чоловіків і 62 жінки віком 22-26 років, хворих на ЦД 1, які проходили стаціонарне лікування в терапевтичних відділеннях №1 і №2 Вінницького обласного високоспеціалізованого ендокринологічного центру. Контрольна група складалась з 8 практично здорових чоловіків і 13 практично здорових жінок аналогічного віку. Усім пацієнтам імунофрерментним методом визначали рівень мікроальбумінурії та цистатину С. Проводили оцінку частоти ангіо-, ретино- та нейропатії, загальноклінічних (систолічний $A T$, діастолічний $A T$, пульс) та антропометричних (зріст, вага, площа поверхні тіла, обхват талії, індекс маси тіла) показників. Статистична обробка отриманих результатів проведена в ліцензійному пакеті "Statistica 5.5", з використанням непараметричних методів оцінки. Встановлено, що в групі чоловіків рівень цистатину C у яких <0,9, та у жінок з рівнем цистатину С>0,9 при наростанні альбумінурії зростає відсоткова частка пацієнтів з важчим ступенем мікросудинних ускладнень ЦД 1. У хворих на ЦД 1 порівняно з контрольною групою величина систолічного артеріального тиску достовірно більша та збільшується по мірі зростання рівня альбуміну в сечі (при цистатині С<0,9 - у чоловіків з нормо-, мікроальбумінурією та протеїнурією на 7,14\%, 8,1\% та 10,8\%; у жінок з нормо-, мікроальбумінурією на 7,5\% та 10,0\%; при цистатині C>0,9 - у чоловіків з нормо-, мікроальбумінурією на 4,9\% та 7,2\%; у жінок з протеїнурією на 19,5\%). Аналогічні зміни встановлені для діастолічного артеріального тиску (при цистатині C<0,9 - у чоловіків з протеїнурією на 13,0\%; у жінок з нормо-, мікроальбумінурією на 11,4\% та 13,4\%; при цистатині C>0,9 - у чоловіків з мікроальбумінурією на 9,0\%; у жінок з нормо- та протеїнурією на 9,5\% та 21,5\%) та величини пульсу (при цистатині C<0,9 - у чоловіків з мікроальбумінурією $і$ протеїнурією на 18,4\% та 12,6\%; у жінок з мікроальбумінурією на 9,13\%; при цистатині С>0,9 - у чоловіків з мікроальбумінурією на 12,0\%; у жінок з нормо-, мікроальбумінурією та протеїнурією на 10,1\%, 16,3\% та 25,3\%). У хворих на ЦД 1 порівняно із контрольною групою величина довжини тіла достовірно менша та зменшується в міру збільшення рівня альбуміну в сечі (при цистатині C<0,9 - у чоловіків з нормо-, мікроальбумінурією та протеїнурією на 3,6\%, 6,7\% та 9,0\%; у жінок з мікроальбумінурією на 1,9\%; при цистатині C>0,9 - у чоловіків з нормо-, мікроальбумінурією на 5,2\% та 7,3\%; у жінок 3 нормоальбумінурією та протеїнурією на 2,6\% та 4,3\%). Аналогічні зміни встановлені у чоловіків для величина маси тіла (при цистатині C<0,9 - з мікроальбумінурією та протеїнурією на 13,6\% і 30,1\%; при цистатині C>0,9 - 3 нормо- $i$ мікроальбумінурією на 10,2\% і 25,4\%) та величини площі поверхні тіла (при цистатині С<0,9 - 3 нормо-, мікроальбумінурією та протеїнурією на 5,8\%, 10,8\% і 18,9\%; при цистатині С>0,9 - з нормо- і мікроальбумінурією на 8,2\% і 16,2\%). Величина 
обхвату талії у хворих чоловіків на ЦД 1 з нормоальбумінурією достовірно більша, а у хворих інших груп достовірно менша порівняно із здоровими досліджуваними (при цистатині С<0,9 - з нормо-, мікроальбумінурією і протеїнурією на 3,8\%, 1,2\% та 5,2\%; при цистатині C>0,9 - з мікроальбумінурією на 5,1\%). У хворих жінок порівняно із здоровими обхват талії достовірно більший (при цистатині С<0,9 - з нормо- і мікроальбумінурією на 11,2\% та 10,7\%; при цистатині С>0,9 - з нормо- та протеїнурією на 9,7\% та 6,0\%). У хворих на ЦД 1 чоловіків з протеїнурією порівняно з контрольною групою величина індексу маси тіла достовірно менша на 9,7\% (цистатин С<0,9). Величина індексу маси тіла достовірно більша у хворих жінок 3 нормоальбумінурією та мікроальбумінурією - відповідно на 11,8\% та 17,7\% (цистатин С<0,9) та у пацієнток з протеїнрією на 7,2\% (цистатин C>0,9) порівняно із здоровими жінками. Таким чином, між здоровими та хворими на ЦД 1 пацієнтами 3 різним ступенем альбумінурії встановлені відмінності загальноклінічних та антропометричних показників, причому вони тим більші, чим більший рівень цистатину С.

Ключові слова: цукровий діабет 1 типу, рівень цистатину C, рівень альбуміну в сечі, ангіо-, ретино- та нейропатія, загально-клінічні показники, антропометричні показники.

\section{ОСОБЕННОСТИ ЧАСТОТЫ АНГИО-, РЕТИНО- И НЕЙРОПАТИИ, ОБЩЕКЛИНИЧЕСКИХ И АНТРОПОМЕТРИЧЕСКИХ ПОКАЗАТЕЛЕЙ У БОЛЬНЫХ САХАРНЫМ ДИАБЕТОМ 1 ТИПА С РАЗЛИЧНЫМ УРОВНЕМ АЛЬБУМИНА В МОЧЕ В ЗАВИСИМОСТИ ОТ УРОВНЯ ЦИСТАТИНА С \\ Кривовяз Ю.А., Вернигородский В.С., Дзевульская И.В., Шевчук Ю.Г., Жученко П.С.}

Цистатин С улучшает стратифрикацию риска среди лиц с диабетической нефропатией относительно риска смертности, сердечно-сосудистых заболеваний, нарушений со стороны органа зрения и нервной системы на доклинической и начальной стадии. Цель исследования - изучить частоту ангио-, ретино- и нейропатии, а также различия общеклинических и антропометрических показателей у больных сахарным диабетом 1 типа (СД 1) с различным уровнем альбумина в моче в зависимости от уровня цистатина С. Выборка составила 78 мужчин и 62 женщины в возрасте 22-26 лет, больных СД 1, которые проходили стационарное лечение в терапевтических отделениях №1 и №2 Винницкого областного высокоспециализированного эндокринологического центра. Контрольная группа состояла из 8 практически здоровых мужчин и 13 практически здоровых женщин аналогичного возраста. Всем пациентам иммунофрерментным методом определяли уровень микроальбуминурии и цистатина С. Проводили оценку частоты ангио-, ретино- и нейропатии, общеклинических (систолическое АД, диастолическое АД, пульс) и антропометрических (рост, вес, площадь поверхности тела, обхват талии, индекс массы тела) показателей. Статистическая обработка полученных результатов проведена в лицензионном пакете "Statistica 5.5", с использованием непараметрических методов оценки. Установлено, что в группе мужчин уровень цистатина $C$ у которых <0,9, и у женщин с уровнем цистатина C>0,9 при нарастании альбуминурии растет процентная доля пациентов с более тяжелой степенью микрососудистых осложнений СД1. У больных СД1 по сравнению с контрольной группой величина систолического артериального давления достоверно больше и увеличивается по мере роста уровня альбумина в моче (при цистатине C<0,9 - у мужчин с нормо-, микроальбуминурией и протеинурией на 7,14\%, 8,1\% и 10,8\%, у женщин с нормо-, микроальбуминурией на 7,5\% и 10,0\%, при цистатине С>0,9 - у мужчин с нормо-, микроальбуминурией на 4,9\% и 7,2\%, у женщин с протеинурией на 19,5\%). Аналогичные изменения установлены для диастолического артериального давления (при цистатине C<0,9 - у мужчин с протеинурией на 13,0\%, у женщин с нормо-, микроальбуминурией на 11,4\% и 13,4\%, при цистатини C>0,9 - у мужчин с микроальбуминурией на 9,0\%, у женщин с нормо- и протеинурией на 9,5\% и 21,5\%) и величины пульса (при цистатине С<0,9 - у мужчин с микроальбуминурией и протеинурией на 18,4\% и 12,6\%, у женщин с микроальбуминурией на 9,13\%, при цистатине C>0,9 - у мужчин с микроальбуминурией на 12,0\%, у женщин с нормо-, микроальбуминурией и протеинурией на 10,1\%, 16,3\% и 25,3\%). У больных СД1 по сравнению с контрольной группой величина длины тела достоверно меньше и уменьшается по мере увеличения уровня альбумина в моче (при цистатине C<0,9 - y мужчин с нормо-, микроальбуминурией и протеинурией на 3,6\%, 6,7\% и 9,0\%, у женщин с микроальбуминурией на 1,9\%, при цистатине C>0,9 - у мужчин с нормо-, микроальбуминурией на 5,2\% и 7,3\%, у женщин с нормоальбуминурией и протеинурией на 2,6\% и 4,3\%). Аналогичные изменения установлены у мужчин для величины массы тела (при цистатине С<0,9 - $c$ микроальбуминурией и протеинурией на 13,6\% и 30,1\%, при цистатине C>0,9 - с нормо- и микроальбуминурией на 10,2\% и 25,4\%) и величины площади поверхности тела (при цистатине $C<0,9$ - с нормо-, микроальбуминурией и протеинурией на 5,8\%, 10,8\% и 18,9\%, при цистатине C>0,9 - с нормо- и микроальбуминурией на 8,2\% и 16,2\%). Величина окружности талии у больных мужчин СД1 с нормоальбуминурией достоверно больще, а у больных других групп достоверно меньще по сравнению со здоровыми испытуемыми (при цистатине C<0,9 - с нормо-, микроальбуминурией и протеинурией на 3,8\%, 1,2\% и 5,2\%, при цистатине C>0,9 - с микроальбуминурией на 5,1\%). У больных женщин по сравнению со здоровыми обхват талии достоверно больще (при цистатине С<0,9 - с нормо- и микроальбуминурией на 11,2\% и 10,7\%, при цистатине С>0,9 - c нормо и протеинурией на 9,7\% и 6,0\%). У больных СД1 мужчин с протеинурией по сравнению с контрольной группой величина индекса массы тела достоверно меньще на 9,7\% (цистатин $C<0,9$ ). Величина индекса массы тела достоверно больше у больных женщин с нормоальбуминурией и микроальбуминурией - соответственно на 11,8\% и 17,7\% (цистатин $C<0,9)$ и у пациенток с протеинурией на 7,2\% (цистатин C>0,9) по сравнению со здоровыми женщинами. Таким образом, между здоровыми и больными СД1 у пациентов с разной степенью альбуминурии установлены различия общеклинических и антропометрических показателей, причем они тем больще, чем больще уровень цистатина С.

Ключевые слова: сахарный диабет 1 типа, уровень цистатина С, уровень альбумина в моче, ангио-, ретино- и нейропатия, общеклинические показатели, антропометрические показатели. 